\title{
EFEKTIFITAS PSIKOEDUKASI KEMAMPUAN EMPATI DALAM MENINGKATKAN TOLERANSI BERAGAMA PADA MAHASISWA SALAH SATU PERGURUAN TINGGI SWASTA DI JAKARTA
}

\author{
THE EFFECTIVENESS OF EMPATHY ABILITY IN PSYCHEDUCATION IN \\ IMPROVING RELIGIOUS TOLERANCE IN COLLEGE STUDENTS ONE OF THE \\ PRIVATE VOCATIONAL SCHOOLS IN JAKARTA
}

\author{
Hania Maria Sofwana ${ }^{1}$, Fitri Rosiana ${ }^{2}$, Handrix Chris Haryanto ${ }^{3}$ \\ ${ }^{123}$ Universitas Paramadina \\ ${ }^{1}$ haniiamarias@gmail.com, ${ }^{2}$ rosy.anna2014@gmail.com, ${ }^{3}$ handrixchrisharyanto@gmail.com
}

\begin{abstract}
Abstrak
Konflik akibat intoleransi hingga saat ini masih sering terjadi dan melibatkan berbagai lapisan masyarakat, salah satunya adalah mahasiswa. Mahasiswa sebagai harapan masa depan bangsa dalam mengemban amanah kepemimpinan dan agen perubahan sosial, kiranya harus dibekali dengan pengetahun, pengalaman, dan kebijaksanaan yang cukup dalam menyikapi pluralitas bangsa yang sangat tinggi. Toleransi beragama mencakup masalah-masalah keyakinan dalam diri manusia yang berhubungan dengan akidah atau ketuhanan yang diyakininya. Salah satu faktor yang memengaruhi toleransi adalah empati. Adapun intervensi yang dapat meningkatkan kemampuan empati salah satunya adalah psikoedukasi. Penelitian ini, bertujuan untuk menguji efektifitas psikoedukasi empati dalam meningkatkan toleransi beragama pada mahasiswa-mahasiswa salah satu perguruan tinggi swasta di Jakarta. Metode penelitian yang digunakan adalah metode penelitian kuasi eksperimen dengan desain dua kelompok non-randomized pretest-posttest control group design. Penelitian ini terdiri dari 94 orang mahasiswa dengan kriteria mahasiswa semester 1 dan semester 3 (dimana 49 mahasiswa semseter 3 sebagai kelompok eksperimen dan 45 mahasiswa semseter 1sebagai kelompok kontrol). Skala toleransi beragama digunakan untuk mengumpulkan data. Hasil penelitian dengan analisis statistik Uji Mann Whitney dan hasil yang diperoleh adalah taraf signifikansi $\mathrm{p}=0,000 \quad(<0,05)$. Hasil yang diperoleh menunjukkan bahwa terdapat perbedaan skor posttest antara kelompok eksperimen dan kelompok kontrol. Kelompok yang mendapat psikoedukasi kemampuan empati menunjukkan peningkatan dalam toleransi beragama dibandingkan kelompok yang tidak mendapat psikoedukasi kemampuan empati. Maka dapat disimpulkan bahwa psikoedukasi kemampuan empati efektif dalam meningkatkan toleransi beragama mahasiswa.
\end{abstract}

Kata Kunci: psikoedukasi, empati, toleransi beragama.

\begin{abstract}
Conflicts due to intolerance are still frequent and involve various levels of society, one of which is students. Students as the hope of the nation's future in carrying out the mandate of leadership and social change agents must be equipped with sufficient knowledge, experience, and wisdom in addressing the nation's plurality that is indeed very high. Religious tolerance is a tolerance that includes issues of belief in human beings that are related to the belief of divinity that he believes in. One of the factors that influence tolerance is empathy. One of the interventions that can improve empathy is psychoeducation. This research aims to examine the effectiveness of empathy psychoeducation in increasing religious tolerance in students of one of the private universities in Jakarta. This research method is a quasi-experimental research method with the design of two groups of Non-Randomized Pretest-Posttest Control Group Design. This research involved 94 students (49 students as the experimental group and 45 students as the control group). The religious tolerance scale is used to collect data. Results of research with statistical analysis are Mann Whitney and the results obtained are a significance level of $p=0,000(<0.05)$. The results obtained indicate that there are differences in posttest scores between the experimental group and the control group. The group that got psychoeducation on empathy ability showed an increase in religious tolerance compared to the group who did not get psychoeducation of empathy ability. So it can be concluded that psychoeducation of empathy ability is effective in increasing student religious tolerance.
\end{abstract}

DOI : https://dx.doi.org/10.26486/psikologi.v22i2.1141

URL : http://ejurnal.mercubuana-yogya.ac.id/index.php/psikologi/index

Email : insight@mercubuana-yogya.ac.id 
Keywords: psychoeducation, empathy, religious tolerance.

\section{PENDAHULUAN}

Indonesia merupakan negara dengan masyarakat yang memiliki keberagaman kelompok, seperti, agama, suku, ras, dan antar golongan. Dengan adanya perbedaan yang sangat beragam menyebabkan risiko konflik yang lebih tinggi terhadap antar kelompok. Salah satunya adalah keberagaman agama. Keanekaragaman agama pada dasarnya memiliki dampak positif, namun juga memiliki dampak negatif bagi penganut agama. Dampak negatif dari keberagaman agama adalah rentan terjadinya perselisihan (Yaqin, 2015). Berdasarkan hasil studi yang dilakukan Centre of Strategic and International Studies (CSIS) pada tahun 2012, menyatakan bahwa toleransi beragama orang Indonesia tergolong rendah. Berdasarkan hasil survei CSIS, sebanyak 59,5\% responden tidak berkeberatan bertetangga dengan orang beragama lain. Sekitar $33,7 \%$ lainnya menjawab sebaliknya. Penelitian ini dilakukan pada bulan Februari tahun 2012 di 23 provinsi yang terdiri dari 2.213 responden. Saat ditanya mengenai pembangunan rumah ibadah agama lain di lingkungannya, sebanyak $68,2 \%$ responden menyatakan lebih baik hal tersebut tidak dilakukan. Hanya 22,1\% yang tidak berkeberatan. Hasil survei tersebut juga menunjukkan bahwa kecenderungan intoleransi pada kelompok masyarakat tersebut berasal dari semua kategori pendidikan. Sekitar 20\% masyarakat berpendidikan SD, SMP, dan, SMA, menyatakan tak keberatan dengan pembangunan rumah ibadah agama lain di lingkungannya. Adapun pada masyarakat dengan pendidikan di atas SMA, hanya sekitar 38,1\% yang menyatakan setuju. Data ini menunjukkan bahwa tingkat toleransi beragama tidak berkorelasi dengan tingkat pendidikan formal. Hal ini cukup miris mengingat bahwa keberadaan agama sendiri dalam penelitian Haryanto (2016) memiliki fungsi salah satunya adalah meningkatkan toleransi.

Toleransi beragama adalah toleransi yang mencakup masalah keyakinan dalam diri manusia yang berhubungan dengan akidah atau ketuhanan yang diyakininya. Seseorang harus diberikan kebebasan untuk meyakini dan memeluk agama (mempunyai akidah) yang dipilihnya, serta memberikan penghormatan atas pelaksanaan ajaran-ajaran yang dianut atau diyakininya (Cassanova, 2008). Pada realitasnya, konflik akibat intoleransi sampai saat ini masih sering terjadi dan melibatkan berbagai lapisan masyarakat termasuk mahasiswa. Mahasiswa sebagai harapan masa depan bangsa dalam mengemban amanah kepemimpinan dan agen perubahan sosial, sehingga harus dibekali dengan pengetahun, pengalaman, dan kebijaksanaan yang cukup dalam menyikapi pluralitas bangsa yang memang sangat tinggi. Toleransi antar umat beragama dapat diwujudkan dalam bentuk antara lain saling menghormati, memberi kebebasan kepada pemeluk agama lain dalam menjalankan ibadah sesuai dengan agama dan kepercayaannya, dan tolong-menolong dalam hidup bermasyarakat (Nisa,et.al, 2016).

Alport (dalam Prawira, 2010) Mengemukakan bahwa toleransi pada diri seseorang dipengaruhi oleh beberapa faktor yang merupakan hasil dari interaksi beberapa faktor. Secara garis besar dikelompokkan dalam 3 faktor utama yakni awal kehidupan, pendidikan, dan kemampuan 
empati. Salah satu faktor yang memengaruhi tolerasi adalah empati. Berdasarkan hasil penelitian yang dilakukan oleh Syaifudin (2017) didapatkan hasil bahwa toleransi beragama dipengaruhi oleh interaksi sosial yang salah satu aspeknya adalah empati. Hal yang sama dikemukakan oleh penelitian Davis \& Kraus (dalam Chow et.al, 2012) bahwa individu yang memiliki empati cenderung lebih toleran.

Empati merupakan kemampuan individu untuk memahami keadaan orang lain, baik secara perasaan dan pikiran dengan mengomunikasikan pikiran dan perasaannya tersebut kepada orang lain tanpa kehilangan identitas dirinya sendiri dengan kata lain. Selain itu, empati merupakan kemampuan individu untuk menempatkan diri pada pikiran dan perasaan orang lain tanpa harus terlibat dalam perasaan maupun tanggapan orang tersebut (Gustini, 2017). Adapun ciri-ciri orang yang memiliki rasa empati yakni mampu menerima dan mendengarkan sudut pandang orang lain, serta memiliki kepekaan perasaan terhadap orang lain (Goleman, 2003). Sedangkan faktor pendorong empati ada tiga yakni, individu mungkin lebih berempati pada orang yang mirip dengan dirinya, individu juga cenderung berempati pada orang yang penderitaannya berasal dari faktor yang tidak bisa dikontrol atau faktor yang tak terduga (seperti, sakit,atau kecelakaan dibandingkan karena faktor malas), serta empati dapat pula ditingkatkan dengan fokus terhadap perasaan seseorang yang membutuhkan bukan dari fakta objektif (Baron \& Bryne, 2005).

Empati terdiri dari dua komponen yakni kognitif dan afektif (Taufik, 2012), namun beberapa teoritikus menambahkan aspek komunikatif sebagai faktor ketiga. Komponen kognitif merupakan komponen yang menimbulkan pemahaman terhadap perasanaan orang lain. Tanpa kemampuan kognitif yang memadai, seseorang dapat gagal dalam memahami kondisi orang lain. Empati sebagai aspek afektif merujuk pada kemampuan menyelaraskan pengalaman emosional pada orang lain. Ada dua komponen dari aspek afektif yang diperlukan agar terjadi pengalaman empati yakni kemampuan untuk merasakan secara emosi dan tingkat reaktifitas emosional yang memadai sehingga membentuk kecenderungan individu untuk bereaksi secara emosional terhadap situasi-situasi yang dihadapi. Sedangkan, komponen empati komunikatif adalah ekspresi dari pikiran empati (intelectual empathy) dan perasaan (empathic emotion) terhadap orang lain yang dapat diekspresikan melalui kata-kata ataupun perbuatan (Rokhmat, 2015).

Hurlock (dalam Juliawati \& Suharnan, 2014) mengemukakan bahwa empati merupakan kemampuan seseorang untuk memahami perasaan dan emosi orang lain serta kemampuan menempatkan diri sendiri sebagai orang lain. Seseorang yang berempati digambarkan sebagai seseorang yang toleran, mampu mengendalikan dirinya, ramah, serta memiliki pengaruh dan juga bersifat humanistik (dalam Juliawati \& Suharnan, 2014). Merasakan empati berarti bereaksi terhadap perasaan orang lain dengan respon emosional yang sama dan sesuai dengan respon orang lain tersebut (Santrock, 2003). Berdasarkan pernyataan tersebut, maka seseorang dapat meningkatkan toleransi salah satunya dengan cara meningkatkan kemampuan empatinya. 
Adapun beberapa intervensi telah dilakukan untuk meningkatkan kemampuan empati, diantaranya adalah psikoedukasi melalui video, roleplay, menulis, program berbasis penguatan sumberdaya psikologis, storytelling, dan solution focused brief counseling. Berdasarkan penelitian yang dilakukan oleh Astarini (2013) didapatkan hasil program berbasis penguatan sumber daya psikologis kurang efektif untuk meningkatkan empati. Selain itu, Ayuni, dkk. (2013) dalam penelitiannya didapatkan hasil bahwa storytelling tidak menunjukkan adanya perubahan empati pada kedua kelompok. Serta pada penelitian yang dilakukan oleh Setyawati, dkk. (2019) didapatkan hasil bahwa solution focused brief counseling memberikan hasil yang tidak efektif untuk meningkatkan empati pada mahasiswa BK tingkat II UNP Kediri. Sedangkan penelitian yang dilakukan Candriasih, dkk. (2012) didapatkan hasil bahwa penerapan bimbingan sosial menggunakan media audio visual efektif meningkatkan empati siswa. Hal yang sama dikemukakan dari penelitian Meidiana, dkk. (2018) yang mengungkapkan bahwasanya pengetahuan responden mengenai empati meningkat setelah diberikan media audio visual, hal tersebut dapat terlihat dari nilai rata-rata empati sesudah di berikan media audio visual menjadi lebih tinggi dibandingkan dengan nilai rata-rata empati sebelum di berikan video. Berdasarkan hasil penelitian Lubis, dkk, (2019) didapatkan hasil bahwa role play dapat meningkatkan empati siswa. Selain itu, penelitian yang dilakukan Reilly (2012), juga menyatakan bahwa kegiatan akting dalam seni teater atau bermain peran dapat meningkatkan empati siswa. Pendapat tersebut didasarkan pada hasil penelitian yang telah dilakukan pada mahasiswa Keck School of Medicine, University of Southern California. Menurut Batt-Rawde, dkk. (2013) salah satu strategi yang bisa digunakan untuk meningkatkan kemampuan empati adalah dengan menulis (Batt-Rawde, dkk., 2013). Berdasarkan paparan di atas, maka peneliti memilih beberapa media yang dianggap berhasil dalam meningkatkan empati, yaitu intervensi psikoedukasi menggunakan media video, role play

Rachmaniah (2012) menjelaskan definisi psikoedukasi yakni pengembangan dan pemberian infomasi dalam bentuk pendidikan pada masyarakat tentang informasi yang berkaitan dengan psikologi atau informasi tertentu yang digunakan untuk mempengaruhi kesejahteraan psikososial masyarakat tersebut. Bentuk psikoedukasi yang dilakukan pada penelitian ini terdiri dari beberapa bentuk menyesuaikan aspek empati yakni kognitif, afektif dan komunikatif. Selanjutnya aspek kognitif dapat dilakukan dengan metode diskusi kasus berdasarkan studi kasus melalui rekaman video, untuk disimak atau dipelajari oleh peserta, kemudian mendiskusikannya dengan panduan pertanyaan-pertanyaan yang disiapkan oleh fasilitator. Peneliti memutarkan video yang bertemakan toleransi beragama dengan durasi 30 menit, yang bertujuan untuk membuat responden berempati terhadap fenomena toleransi beragama. Menurut Baron dan Byrne (2005) film dapat memberikan efek positif bagi penontonnya yaitu dapat meningkatkan wawasan seseorang mengenai empati. Seseorang akan merasa empati terhadap karakter fiktif sebagaimana kepada korban dalam kehidupan nyata. Lazimnya, diskusi akan difokuskan pada isu-isu yang terdapat di dalam situasi yang dideskripsikan dalam film tersebut seperti tindakan apa yang perlu dilakukan 
atau pelajaran-pelajaran apa yang dapat dipetik, serta cara mengatasinya, atau mencegah agar situasi sejenis tidak terjadi pada waktu yang akan datang (Supratiknya, 2011).

Pada aspek afektif dapat dilakukan dengan metode role playing (Kusheriyanti, 2018). Peneliti membuat rancangan cerita mengenai fenomena-fenomena perbedaan agama yang banyak dijumpai dalam kehidupan sehari-hari kemudian responden perankan. Menurut, Blatner dalam Komalasari (2010) menyatakan bahwa model pembelajaran role playing merupakan eksplorasi situasi sosial yang komplek, dimana hal tersebut ditekankan pada keterlibatan emosional dan alat indra ke dalam situasi masalah yang dihadapinya. Role-play atau bermain peran dilakukan dengan cara mengajak siswa untuk dapat merasakan dunia dari sudut pandang orang lain. Hal tersebut dilakukan dengan cara membayangkan bahwa dirinya yang menjadi orang tersebut, bersikap dan dapat menyelami perasaan orang tersebut (be other person). Sedangkan, dalam meningkatkan empati pada aspek komunikatif dapat dilakukan dengan menggunakan metode menulis surat dengan pesan perdamaian mengenai toleransi beragama. Peneliti meminta responden untuk menuliskan sebuah pesan terhadap teman yang berbeda agama, sehingga mereka dapat mengungkapkan perasaannya terhadap teman yang berbeda agama melalui tulisan. Kemampuan menulis merupakan bentuk komunikasi secara tidak langsung, tidak bertatap muka dengan orang lain. Salah satu tujuan dari menulis adalah untuk mengungkapkan perasaan (Tarigan, 2008). Menulis dapat digunakan sebagai sarana untuk mengungkapkan empati kepada seseorang. Menulis juga merupakan salah satu strategi yang dapat digunakan untuk meningkatkan kemampuan empati seseorang (Batt-Rawde, dkk., 2013).

Adanya empati dalam toleransi, membuat seseorang tidak dengan mudah menjustifikasi perihal pemahaman, ucapan, atau tindakan orang lain yang berlainan dengan prinsip, nilai, atau agama yang dianutnya. Hal tersebut lantaran empati memungkinkan seseorang untuk berpikir dari sudut pandang orang lain (Abdillah, 2017). Toleransi membuat individu dapat memosisikan diri sebagai orang lain, perspektif individu dalam memandang suatu permasalahan tidaklah sempit, sehingga apa yang Ia anggap sebagai masalah sebelumnya bisa jadi tidak menjadi masalah. Berdasarkan dinamika penelitian di atas, peneliti berhipotesis bahwa metode psikoedukasi kemampuan empati dapat meningkatkan toleransi beragama pada mahasiswa salah satu perguruan tinggi swasta di Jakarta.

\section{METODE}

Metode yang digunakan dalam penelitian ini adalah metode kuantitatif eksperimental. Metode eksperimental merupakan metode penelitian yang menguji hipotesis dalam bentuk hubungan sebabakibat melalui pemanipulasian variabel independen dan menguji perubahan yang diakibatkan oleh pemanipulasian tersebut (Sunarti, 2009). Metode penelitian ini adalah metode penelitian kuasi eksperimen, karena pengambilan sampel tidak dilakukan secara acak. Peneliti menggunakan dua kelompok dalam penelitian ini yakni kelompok kontrol dan kelompok eksperimen. Pada dua 
kelompok dilakukan dua kali pengukuran yaitu pretest dan posttest. Lebih lanjut, kelompok eksperimen akan diberikan perlakuan psikoedukasi empati sedangkan kelompok kontrol tidak. Penelitian ini menggunakan desain dua kelompok Nonrandomized Pre-test-Post-test Control Group Design. Berikut merupakan gambar desain dalam penelitian ini:

Tabel 1. Tabel gambaran desain dua kelompok

\begin{tabular}{cccc}
\hline Grup & Pre-test & Variabel terikat & Post-test \\
\hline Eksperimen & $\mathrm{Y}_{1}$ & $\mathrm{X}$ & $\mathrm{Y}_{1}$ \\
Kontrol & $\mathrm{Y}_{2}$ & - & $\mathrm{Y}_{2}$ \\
\hline
\end{tabular}

Desain dua kelompok Nonrandomized Pretest-Posttest Control Group Design (Sukardi, 2005). Penelitian dilakukan di salah satu perguruan tinggi swasta di Jakarta. Responden terdiri dari 94 mahasiswa (49 mahasiswa sebagai kelompok eksperimen dan 45 mahasiswa sebagai kelompok kontrol. Responden adalah mahasiswa semester 1 dan semester 3. Dengan semester 1 sebagai kelompok kontrol dan semester 3 sebagai kelompok eksperimen. Berikut data responden:

Tabel 2. Data jumlah responden

\begin{tabular}{ccc}
\hline No. & Semester & Jumlah \\
\hline 1. & 1 & 45 \\
2. & 3 & 49 \\
\hline Total & & 94 \\
\hline
\end{tabular}

Teknik pengumpulan data dilakukan dengan menggunakan kuesioner toleransi beragama pada penelitian yang dilakukan oleh Mahardhika (2015). Kuesioner ini berlandaskan teori dari allport mengenai aspek-aspek toleransi serta sudah diukur validitas dan reliabilitasnya. Skala yang digunakan adalah skala model likert. Setiap kategori memiliki nilai sebagai berikut:

Tabel 3. Skor pernyataan positif dan negatif

\begin{tabular}{ccc}
\hline Item Favourable & Item Unfavourable & Skor \\
\hline SS (Sangat Setuju) & STS (Sangat Tidak Setuju) & 4 \\
S (Setuju) & TS (Tidak Setuju) & 3 \\
TS (Tidak Setuju) & S (Setuju) & 2 \\
STS (Sangat Tidak Setuju) & SS (Sangat Setuju) & 1 \\
\hline
\end{tabular}

Tabel 4. Blue print skala toleransi beragama

\begin{tabular}{|c|c|c|c|}
\hline Aspek & Indikator & Favourable & Unfavourable \\
\hline Etnic Attitude & $\begin{array}{l}\text { - Melihat latar belakang } \\
\text { orang lain. } \\
\text { - Melihat kesamaan } \\
\text { latar belakang orang } \\
\text { lain } \\
\text { - Mengutamakan latar } \\
\text { belakang yang sama. }\end{array}$ & $1,3,5,7$ & $2,4,6,8$ \\
\hline Non-Etnic Attitude & $\begin{array}{l}\text { - Melakukan suatu hal karena } \\
\text { sudah menjadi aturan. } \\
\text { - Memandang semua orang } \\
\text { sama. } \\
\text { - Menaati peraturan yang } \\
\text { utama dibandingkan } \\
\text { melihat latar belakang } \\
\text { yang sama. }\end{array}$ & $9,11,13,15$, & $\begin{array}{l}10,12, \quad 14, \\
16,\end{array}$ \\
\hline
\end{tabular}


Tabel 5. Norma skor alat ukur Toleransi Beragama

\begin{tabular}{cc}
\hline Kategori & Rentangan \\
\hline Tinggi & $\mathrm{M}+1 \mathrm{SD} \leq \mathrm{X}$ \\
& $40+7 \leq \mathrm{X}$ \\
& $47 \leq \mathrm{X}$ \\
Sedang & $\mathrm{M}-1 \mathrm{SD} \leq \mathrm{X}<\mathrm{M}+1 \mathrm{SD}$ \\
& $40-7 \leq \mathrm{X}<40+7$ \\
& $33 \leq \mathrm{X}<47$ \\
Rendah & $\mathrm{X}<\mathrm{M}-1 \mathrm{SD}$ \\
& $\mathrm{X}<40-7$ \\
& $\mathrm{X}<33$ \\
\hline
\end{tabular}

Uji validitas alat ukur ini berasal dari perhitungan uji instrumen angket mengenai tingkat toleransi beragama pada penelitian Mahardhika (2015) dan diperoleh sebanyak 16 item pernyataan yang valid. Adapun untuk reliabilitasnya, memiliki reliabilitas sempurna dimana skor faktor tersebut merupakan "True Score" dari variabel Toleransi Beragama, sehingga hasil analisis regresi lebih akurat dan terpercaya. Didapatkan hasil koefisien realibilitas dengan alpha cronbach dari 16 item skala toleransi adalah 0,751 . Rentang nilai validitas skala toleransi beragama dari 0,213 hingga 0,474. Konstruk dikatakan reliabel jika memiliki nilai cronbach alpha sebesar 0,7 (Sekaran, 2003). Namun, terdapat beberapa item yang memiliki nilai corrected item-total correlation dibawah 0,30. Jika item dengan corrected item-total correlation dibawah 0,3 dihilangkan maka dapat menaikan nilai alpha cronbach. Sehingga item nomor 1, 3, 4, 6, 13, dan 16 peneliti hilangkan. Dengan menghilangkan 6 item dan tersisa 10 item, nilai alpha Cronbach naik menjadi 0,757 . Selanjutnya peneliti melakukan tes realibilitas menggunakan pretest pada kelompok ekperimen dan kelompok kontrol.

Berdasarkan kedua hasil analisis pretest pada kedua kelompok terdapat hubungan signifikan antara kedua hasil pengukuran pertama (pre-test) dan kedua (post-test). Kelompok kontrol ( $\mathrm{r}=$ 0,521; $\mathrm{p}<0.001)$, kelompok eksperimen $(\mathrm{r}=0.989, \mathrm{p}<0.001)$. Hasil tersebut menunjukkan bahwa pengukuran yang dilakukan stabil dari waktu ke waktu (reliabel).

Prosedur penelitian yang dilakukan terbagi menjadi dua tahap yakni, tahap persiapan dan tahap pelaksanaan intervensi. Tahap persipan peneliti mempersiapkan instrument dengan mengadaptasi kuesioner Mahardika (2015) dengan melakukan expert judgement kepada dosen psikologi, membuat perizinan penelitian dan penentuan subjek penelitian. Selanjutnya tahap pelaksanaan diawali dengan pemberian pretest pada mahasiswa dengan pengisian kuesioner toleransi beragama yang berjumlah 16 item, kepada kelompok eksperimen dan kelompok kontrol dengan hasil kedua kelompok berada dalam kategori rendah dan sedang. Lalu melakukan intervensi dengan menggunakan psikoedukasi pada kelas eksperimen dan tidak memberikan perlakuan apapun pada kelompok kontrol. Setelah intervensi satu minggu, kemudian dilakukan posttest kepada kelompok eksperimen dan kelompok kontrol. Berdasarkan hasil posttest peneliti melakukan 
analisis data dan selanjutnya tahap kesimpulan terhadap penelitian yang telah dilakukan berdasarkan hipotesis yang telah dirumuskan.

Pada penelitian ini peneliti membuat rancangan intervensi psikoedukasi yang dibagi menjadi dua sesi yakni sesi pertama yaitu menonton video mengenai "film pendek" dalam bentuk materi presentasi tentang empati seseorang terhadap perbedaan agama dalam bentuk powerpoint yang peneliti convert dalam bentuk video dan dengan durasi waktu 60 menit. Dalam 60 menit, peneliti memutarkan video berdurasi 30 menit mengenai empati seseorang terhadap perbedaan agama, selanjutnya peneliti akan membuka diskusi dengan mahasiswa mengenai video yang sudah ditonton. Intervensi kedua yakni role play selama 90 menit, dimana peneliti membentuk kelompok menjadi 5 kelompok, lalu meminta masing-masing kelompok untuk memerankan role play dengan tema yang telah ditentukan oleh peneliti dan membuka diskusi mengenai apa yang telah diperankan oleh responden. Untuk sesi kedua yaitu menulis surat dengan durasi 30 menit, yaitu peneliti meminta responden untuk menuliskan pesan kesesama teman lalu peneliti membacakan beberapa surat di depan kelas.

Pada perhitungan penelitian yang telah dilakukan, teknik analisis data yang digunakan adalah teknik Uji Mann Whitney, karena pengambilan sampel dalam penelitian ini tidak dilakukan secara acak. Menurut Artaya, Uji Mann Whitney merupakan uji non parametris yang bertujuan untuk mengetahui perbedaan median 2 kelompok bebas dengan skala data ordinal, interval atau ratio dimana data tersebut tidak berdistribusi normal (Artaya, 2018).

\section{HASIL DAN PEMBAHASAN}

Pengujian hipotesis pada penelitian ini dilakukan untuk melihat apakah hipotesis yang diasumsikan peneliti di terima atau di tolak. Uji hipotesis dilakukan menggunakan teknik analisis statsitik Uji Mann Whitney untuk melihat perbedaan efektivitas psikoedukasi kemampuan empati kelompok kontrol dan kelompok eksperimen dan didapatkan hasil sebagai berikut :

Hasil analisis menunjukkan nilai signifikansi (Asymp. Sig. 2-Tailed) adalah 0,000 (lebih kecil dari 0,05$)$. Sehingga dapat disimpulkan bahwa terdapat perbedaan efektivitas psikoedukasi kemampuan empati pada kelompok kontrol dan kelompok eksperimen. Hasil analisis tersebut menunjukkan bahwa nilai rata-rata hasil atau mean untuk kelompok kontrol adalah sebesar 23,00 sementara untuk kelompok eksperimen sebesar 70,00. Dengan demikian secara deskriptif statistic dapat disimpulkan disimpulkan bahwa hipotesis peneliti yaitu psikoedukasi kemampuan empati efektif dalam meningkatkan toleransi beragama mahasiswa yang terlibat dalam penelitian ini diterima.

Hasil uji hipotesis yang dilakukan dengan menggunakan uji hipotesis Mann Whitney menunjukkan bahwa program psikoedukasi kemampuan empati efektif dalam meningkatkan toleransi beragama mahasiswa. Hasil penelitian menunjukan adanya perbedaan hasil antara 
kelompok kontrol dan eksperimen. Hal ini didukung dengan fakta bahwa penelitian sebelumnya yang dilakukan oleh Fidiyaningrum (2006) menyatakan psikoedukasi dapat meningkatkan empati secara signifikan. Adapun penelitian lain mengenai toleransi beragama dan psikoedukasi, dilakukan oleh Sulistian (2015) bahwa toleransi beragama dapat ditingkatkan melalui psikoedukasi menggunakan video. Sedangkan berdasarkan penelitian yang dilakukan Candriasih, dkk. (2012) didapatkan hasil, penerapan bimbingan sosial menggunakan media audio visual dapat meningkatkan empati siswa.

Hal yang sama dikemukakan dari hasil penelitian yang dilakukan oleh Meidiana, dkk (2018) yang mengungkapkan bahwa responden memiliki pengetahuan mengenai empati yang meningkat setelah diberikan media audio visual. Hal tersebut terlihat dari nilai rata-rata setelah di berikan media audio visual lebih tinggi dibandingkan dengan nilai rata-rata sebelum di berikan video. Berdasarkan hasil penelitian Lubis, dkk. (2019) didapatkan hasil bahwa role play dapat meningkatkan empati siswa. Reilly, JM (2012) juga menyatakan bahwa kegiatan berakting dalam seni teater atau bermain peran dapat meningkatkatkan empati seseorang. Pendapat tersebut didasarkan pada hasil penelitian yang dilakukan pada mahasiswa Keck School of Medicine, University of Southern California. Menurut Batt-Rawde, dkk. (2013) bahwa kegiatan menulis juga merupakan salah satu strategi yang bisa digunakan untuk meningkatkan kemampuan empati seseorang.

Kemampuan empati disebut juga sebagai intelegensi sosial atau kepekaan sosial. Empati menjadi dasar atau prediktor dalam menumbuhkan nilai-nilai kebaikan, seperti sikap menolong, toleransi, cinta, persahabatan, pemaafan, sharing, dan perilaku prososial lainnya. Empati yang dilakukan seseorang dapat mereduksi intoleransi, adanya konflik, diskriminasi yang terjadi dan meningkatkan pemahaman seseorang, rasa hormat, serta toleransi antara manusia walaupun terdapat perbedaan etnis dan latar belakang budaya (Wang, dkk., 2003). Empati itu sendiri memiliki pengertian sebagai kemampuan individu untuk memahami keadaan orang lain, baik secara perasaan maupun pikiran dengan mengomunikasikan pikiran maupun perasaannya tersebut kepada orang lain tanpa kehilangan identitas dirinya sendiri. Dengan kata lain, empati merupakan kemampuan individu agar dapat menempatkan diri pada pikiran dan perasaan orang lain tanpa harus melibatkan perasaan maupun tanggapan orang tersebut (Gustini, 2017). Orang yang memiliki toleransi tinggi lebih akurat dalam menentukan kepribadian orang lain, mereka juga mempunyai kemampuan menempatkan diri pada keadaan orang lain. Mereka peka terhadap prasangka pemikiran orang lain. Hal yang senada juga dikemukakan oleh Goleman (1997) bahwa salah satu ciri dari kemampuan empati adalah mampu menerima sudut pandang orang lain, yang artinya individu mampu memandang permasalahan dari pola pikir orang lain sehingga akan menimbulkan toleransi dan kemampuan menerima adanya perbedaan pendapat.

Kelemahan dari penelitian ini adalah tidak dilakukan pembagian secara acak antara kelompok kontrol dan kelompok eksperimen sehingga ada faktor kematangan yang mungkin 
berpengaruh pada hasil penelitian. Dengan demikian, hasil penelitian juga hanya bisa digeneralisasikan pada responden penelitian saja. Kemudian peneliti tidak melakukan pengukuran empati sebelumnya, peneliti hanya menggunakan hasil study preliminary yang didapatkan. Selain itu, skala toleransi yang ditentukan oleh peneliti hanya mengukur sikap bukan perilaku, sehingga kurang dapat dipertanggungjawabkan jawaban responden. Namun demikian, psikoedukasi kemampuan empati ini dapat dijadikan acuan bagi universitas untuk menyusun program kemahasiswaan dalam rangka meningkatkan toleransi mahasiswanya.

\section{KESIMPULAN}

Berdasarkan analisis data yang telah dilakukan peneliti maka dapat disimpulkan bahwa psikoedukasi kemampuan empati efektif dalam meningkatkan toleransi beragama pada mahasiswa yang terlibat dalam penelitian ini. Maka, hipotesis bahwa psikoedukasi kemampuan empati efektif dalam meningkatkan toleransi beragama pada mahasiswa yang terlibat dalam penelitian ini telah terbukti. Berdasarkan hasil penelitian, peneliti memiliki beberapa saran terkait dengan psikoedukasi kemampuan empati efektif dalam meningkatkan toleransi beragama mahasiswa. Adapun saran yang dapat diberikan bagi peneliti selanjutnya. Selain itu, dalam melakukan pengukuran empati terhadap responden sebelum dilakukan pretest. Serta, peneliti selanjutnya dapat menentukan skala toleransi beragama sampai pada penilaian perilaku.

\section{DAFTAR PUSTAKA}

Artaya, I. P. (2018). Uji Mann Whitney-U. Metode Analisis Penelitian Kualitatif, 21-29.

Astarini, I. (2013). Peningkatan empati melalui program berbasis penguatan sumber daya psikologis pada siswi kelas VII SMP Muhammadiyah 2 Yogyakarta. Skripsi. UIN Sunan Kalijaga. Yogyakarta.

Ayuni, R. D., Siswati, \& Rusmawati, D. (2013). Pengaruh storytelling terhadap perilaku empati anak. Jurnal Psikologi Undip, 81-130.

Baron, R. A., \& Bryne, D. (2005). Psikologi sosial jilid 2. Jakarta: Erlangga Brigham.

Batt-Rawden., Chisolm., Anton., \& Flickinger. (2013). Teaching empathy to medical students : An updated, systematic review. Academic Medicine, 1171-1177.

Candriasih, N. W., dkk. (2012). Penerapan bimbingan sosial berbantuan media audio visual untuk mengembangkan empati siswa kelas VIIID SMP Negeri 2 Sawan Tahun Pelajaran 2012/2013. Skripsi. Universitas Pendidikan Ganesha. Singaraja.

Cassanova. (2008). Public religious in the modern world. Chicago: Chicago University Press.

Chow, C.M., Ruhl, H., \& Buhrmester, D. (2012). The Mediating role of interpersonal competence between adolescents empathy and friendship quality : A dyadic approach. Journal of Adolescence, 191-200.

Goleman, D. (2003). Working with emotional intelligence. New York: Bantam books. 
Gustini, N. (2017). Empati kultural pada mahasiswa. JOMSIGN: Journal of Multicultural Studies in Guidance and Counseling, 17-34.

Haryanto, H. C. (2016). Apa manfaat dari agama? (Studi pada masyarakat beragama islam di Jakarta. Insight, 18(1), 19-31.

Juliawati, \& Suharnan. (2014). Religiusitas, empati dan perilaku prososial jemaat GKT Hosana Bumi Permai. Persona, Jurnal Psikologi Indonesia, 130-140.

Komalasari, K. (2010). Pembelajaran kontekstual: Konsep dan aplikasi. Bandung: Refika Aditama.

Kusheriyanti, I. (2018). Pengaruh pelatihan empati terhadap perilaku cyberbullying pada remaja. Skripsi. Surabaya: UIN Sunan Ampel Surabaya.

Lubis, N. M. (2019). Pengaruh model pembelajaran role playing terhadap hasil belajar siswa kelas IV MIN 8 Medan kecamatan Medan Petisah pada mata pelajaran pendidikan kewarganegaraan (PKN). Skripsi. Sumatera Utara: UIN Sumatera Utara.

Mahardika, G. (2015). Makna toleransi beragama dalam film muallaf karya Yasmin Ahmad (Kajian analisis semiotik model Roland Barthes). Skripsi. UIN Syarif Hidayatullah Jakarta. Jakarta.

Meidiana, R., Simbolon, D., \& Wahyuni, A. (2018). Pengaruh edukasi melalui media audio visual terhadap pengetahuan dan sikap remaja overweight. Jurnal Kesehatan , 478-484.

Nisa, Z.-u., Inayat,A., \& Yu, Y. (2016). Constitutive overexpression of myo-inositol-1-phosphate synthase gene (GsMIPS2) from Glycine Soja Confers enhanced salt tolerance at various growth stages in Arabidopsis. Journal of Northeast Agricultural University, 28-44.

Prawira, R. (2010). Hubungan antara makna hidup dengan toleransi beragama pada jamaah Salafy di Bekasi. Skripsi. UIN Syarif Hidayatullah Jakarta. Jakarta.

Rachmaniah, D. (2012). Pengaruh psikoedukasi terhadap kecemasan dan coping orang tua dalam merawat anak dengan thalasemia mayor di RSU Kabupaten Tangerang Banten. Skripsi. Depok: Universitas Indonesia.

Reilly, J., Trial, \& Schaff, P. (2012). Using theater to increase empathy training in medical students. Journal for Learning through the Arts, 1-8.

Rokhmat, A. (2015). Pengaruh pemahaman dampak buruk rokok terhadap empati perokok. Skripsi. Universitas Islam Negeri Maulana Malik Ibrahim. Malang.

Santrock, J. (2003). Adolescence, perkembangan remaja (6th ed.; Terj.). Jakarta: Erlangga.

Sekaran, U. (2003). Metode penelitian untuk bisnis edisi 4. Jakarta: Salemba.

Setyawati, S. P., dkk. (2019). Penerapan solution focused brief counseling untuk meningkatkan empati mahasiswa bimbingan dan konseling. Jurnal Hasil-Hasil Penelitian Universitas Nusantara PGRI Kediri (e-Journal), 41-49.

Sukardi, 2005. Metodelogi penelitian pendidikan, kompetensi dan prakteknya. Jakarta: Bumi Aksara.

Sunarti. (2009). Metode-metode Penelitian. Bandung: Alfabeta. 
Supratiknya, A. (2011). Merancang program dan modul psikoedukasi. Yogyakarta: Universitas Sanata Dharma.

Tarigan, H. G. (2008). Menulis: Sebagai suatu keterampilan berbahasa. Bandung: Angkasa.

Taufik. (2012). Empati pendekatan psikologi sosial. Jakarta: Raja Grafindo Persada.

Wang, Y.-W., Davidson, M. M., Yakushko, O. F., Savoy, H. B., Tan, J. A., \& Bleier, J. K. (2003). The scale of ethnocultural empathy: Development, validation, and reliability. Journal of Counseling Psychology, 50(2), 221-234.

Yaqin, A. (2015). Nilai-nilai multikultural dalam kehidupan mahasiswa difabel di Universitas Islam Negeri Sunan Kalijaga Yogyakarta . Thaqafiyyat, 98-120. 